TITLE:

CONTRIBUTION TO JAPANESE ASCIDIAN FAUNA. -II. NOTES ON SOME ASCIDIANS COLLECTED CHIEFLY ALONG THE COAST OF KII PENINSULA-

$\operatorname{AUTHOR(S):~}$

Tokioka, Takasi

CITATION:

Tokioka, Takasi. CONTRIBUTION TO JAPANESE ASCIDIAN FAUNA. -II. NOTES ON SOME ASCIDIANS COLLECTED CHIEFLY ALONG THE COAST OF KII PENINSULA-. PUBLICATIONS OF THE SETO MARINE BIOLOGICAL LABORATORY 1949, 1(2): 39-64

ISSUE DATE:

1949-12-25

URL:

http://hdl.handle.net/2433/174434

RIGHT: 


\section{CONTRIBUTION TO JAPANESE ASCIDIAN FAUNA II. NOTES ON SOME ASCIDIANS COLLECTED CHIEFLY ALONG THE COAST OF KII PENINSULA*}

\section{Takasi ToKIOKA}

\section{With Plate VIII and 16 Text-figures}

The present material consists of several specimens collected by Dr. S. Shino at Sugasima, Prov. Sima, and those collected by the members of the Laboratory in the vicinity of Seto. I express here my hearty thanks to these gentlemen for their kindness in offering me the material, and to Prof. T. KOMAI for his kind guidance and incessant encouragement during the course of this study. I a'so record here my indebtedness to the Ministry of Education for the financial aic for pursuing the present study.

\section{Pseudodistoma antinboja n. sp.}

(Fig. 1 ; Pl. VIII, fig. 1)

A colony was hauled by a lobster net at Seto in A pril 1942. It consists of five cormidia, the largest one of which is $26 \mathrm{~mm}$ in diameter and $65 \mathrm{~mm}$ in height. Each cormidium is somewhat mushroom-shaped, and consists of a reddish orange corona and a brownish peduncle which is covered with a thin pellicle, and contains long abdominal segments of zooids in it.

Zooids: All zooids are more or less contracted and ca. $30 \mathrm{~mm}$ long in large individuals. Eash zooid is divided into three portions: thorax, abdomen and postabdomen, of which the last portion is very long and may occupy about $4 / 5-5 / 6$ of the body. Thorax and abdomen are coloured reddish orange, nearly same in length and clothed with a mantle which is furnished with welldeveloped longitudinal musculature. Many zooids are devoid of postabdomen, or constricted strongly between the abdomen and postabdomen. In some zooids

* Contributions from the Seto Marine Biological Laboratory, No. 124

Publ. Seto Mar. Biol. Lab., I (2) 1949. 
the postabdomen is very short and devoid of the posterior portion containing testicular follicles, although an ovum is always found at its bottom. Both the branchial and atrial apertures are 6-lobed and the siphons are very short. Thorax: With elongate stigmata arranged in three rows, each consisting of 8-9 stigmata, Tentacles ca. 16, large and small ones being arranged alternately. Dorsal tubercle elliptical, and with a short transverse slitlike ciliated groove. Two dorsal languets displaced considerably to the left side from the dorsomedian line.

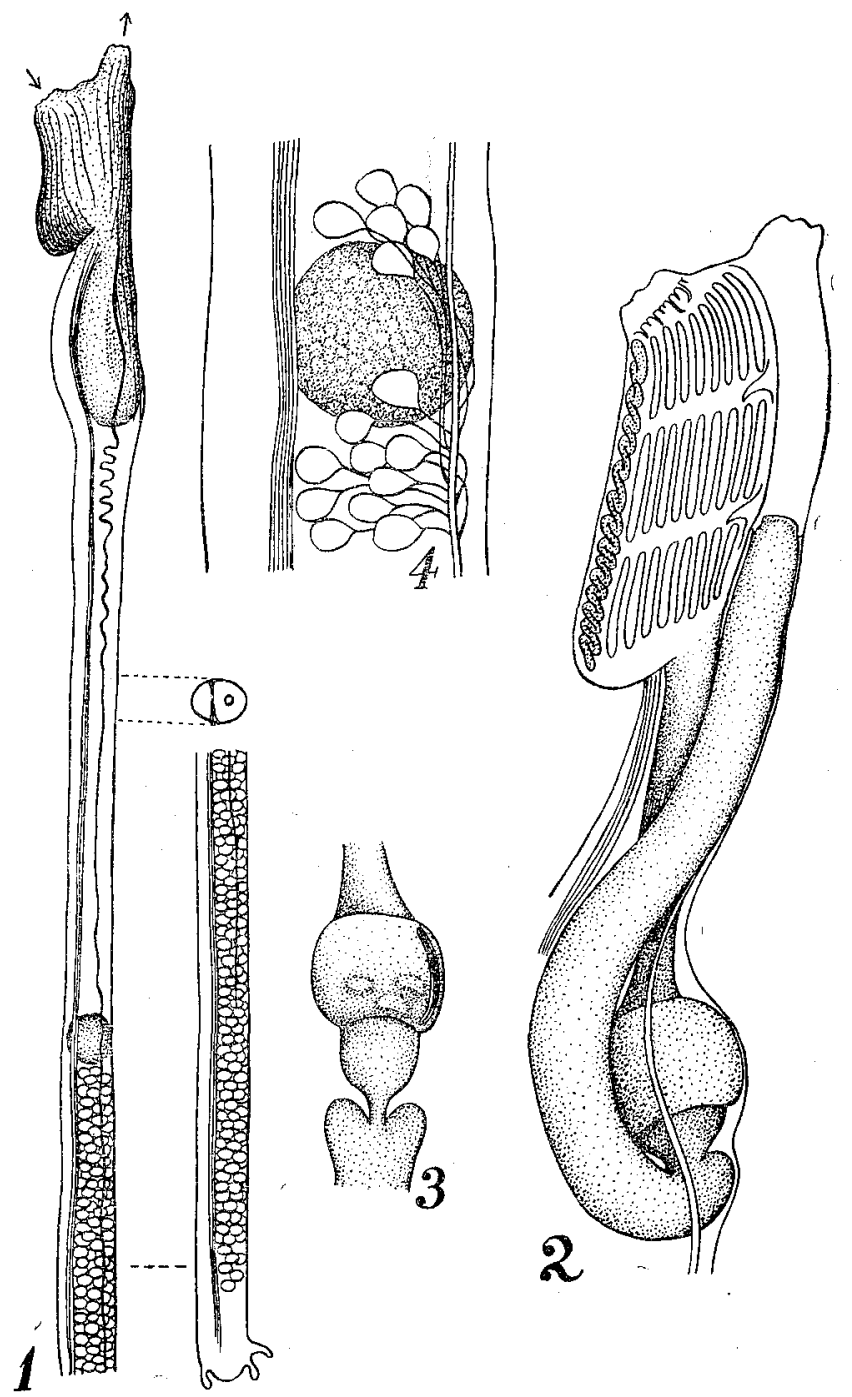

Fig 1. Pseudodistoma antinboja n. sp. 1….Zooid; 2.....Thorax and abdomen ; $3 \cdots .$. Stomach ; $4 \cdots .$. Ovum and some testicular follicles. 
Abdomen: Intestinal loop narrow. Oesophagus rather thick. Stomach situated near the posterior end of the abdomen, has smooth surface, although several irregular patterns may be formed unders trong contraction. Mid-intestine very short. Rectum provided with a pair of small caeca at its proximal end. Anus bilobed, and situated at the level between the 2 nd and 3rd rows of stigmata. Postabdomen: Divided by a longitudinal septum into a wide and a narrow tube. The latter is hollow throughout its length, while the former contains an ovum in the middle, and stuffed with testicular follicles in its posterior portion. The vas deferens is undulating in many specimens, apparently due to contraction of zooids.

This is the second species of the genus Pseudodistoma which has been represented by $P$. cereum IMICHAELSEN found at Stewart Island. The name of the new species is derived from Antin, the hero of the farnous local legend "Dôzyôzi Monogatarì".

\section{Ritterella yamazii n. sp.}

(Fig. 2)

One colony was found by Mr. I. YAMAzI at Ezura near the Laboratory in June 1948. It is $20 \times 17 \mathrm{~mm}$ in extent and $4 \mathrm{~mm}$ in thickness, and covers the carapace of a small crab, Cryptodromia tuberculata STIMPson. Another colony was found by Mr. T. Yамамото in August 1949 at Hatakezima in Tanabe Bay. The test is soft and semitransparent; zooids are arranged with their ventral sides towards the periphery of the colony, whitish in colour, and marked with yellowish tint along alimentary canals which contain many faecal pellets. Zooids: About $4 \mathrm{~mm}$ in length. Body divided into thorax, abdomen and postabdomen, of which the last part is slightly shorter than the rest taken together. Thorax: Branchial aperture 6-lobed. Atrial aperture situated at the level between the 2 nd and 3 rd rows of stigmata and with smooth margins. Siphons very short. Ca. five longitudinal muscles occur on each side of the thorax. Tentacles about 8 . Stigmata elongate and arranger in 5 rows, each row consisting of about 10 stigmata. Dorsal lamina represented by a series of four languets. Ciliated groove is a small orifice. Embryos, up to four in number, enclosed in a brood pouch which is a swelling of the atrial cavity on the right side of the thorax. A small gland-like body is found on the dorso-median line behind the second dorsal languet, just opposite the atrial aperture. The details of this body can rot be made out, since all zooids are more or less contracted.

Abdomen: Slightly shorter than the thorax, and coated along the sides of the 


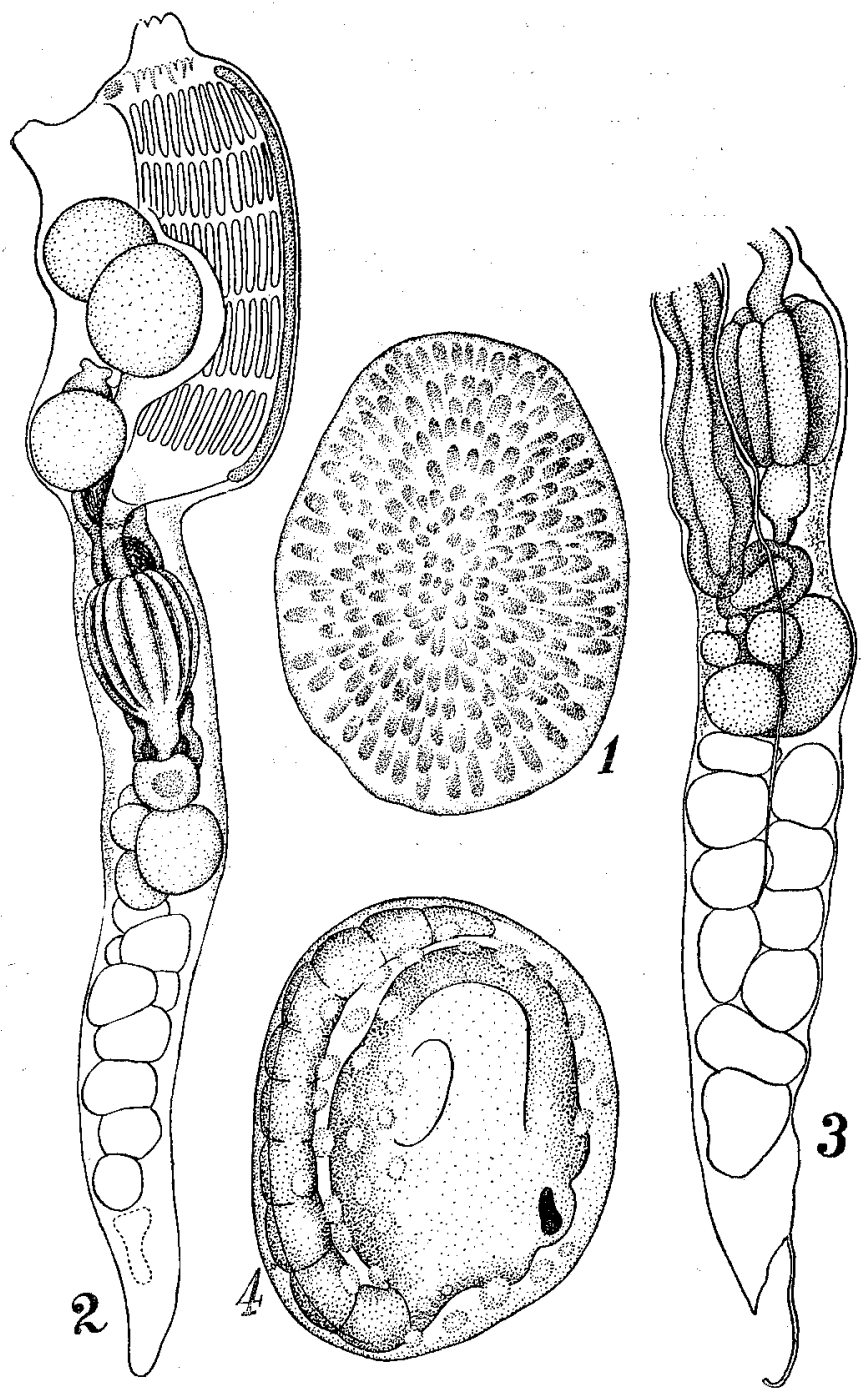

Fig 2. Ritterella yamazii n. sp. 1… Entire colony; $2 \cdots \cdots$ Right side of zooid, $\times 12 ; 3 \cdots$. Left side of the posterior half of the zooid, $\times 12 ; 4 \cdots .$. Embryo, $\times 110$.

alimentary canal with a loose tissue which continues posteriorly to the posterior end of the testicular follicle row in the postabdomen. Oesophagus short. Stomach situated near the middle of the abdomen and with about 10 longitudinal folds on the surface. Mid-intestine constricted distinctly in the middle, and divided into an anterior and a posterior portion; and continues into a rectum at the 
posterior end of the intestinal loop. Anal opening at the level between the 4 th and 5th rows of stigmata and fringer with two incon picuous lobes.

Postabdomen: Ovary situater just behind the intestinal loop and contains ova less than five in many zooids. Testis consists of 10-12 testicular follicles arranged roughly in two rows. Heart occurs near the posterior end of each zooid.

Remarks: The atrial apertures of zooids in the present specimen seem to open directly on the surface of the colony. This feature $n$ akes the pecimen referable to the genus Ritterella established by HARANT in 1931 (= Sigillinaria OKA 1933). Among the species of Amaroucium, Am. arenatum VAN NAME from Californian coast has only 5 rows of stigmata as in the present species. It is, however, much larger than the present species, and forms a colony quite differnt from that of the latter.

\section{Didemnum moseleyi (HERDMAN) 1886.}

(Fig. 3)

I refer with some doubt to the present species a colony which encrusted the surface of Pyura michaelseni var. depressa found by Dr. SHINo at Suga ima. The colony is $30 \times 2 \mathrm{Jmm}$ in extent. Calcareous spicules in the test are distributed unevenly, densely in some parts and more dispersely in the other. In the former parts, the surface looks whitish aud shows branchial apertures of zooids in dark colour, where the spicules are very scarce. In other parts. zooids are seen through the test as whitish boties, because of the presence of compact aggregations of spicules in large numbers around the thorax of the zooid. Spicules are imbedded mainly in the surface layer, while they are very sparse in the lower layer. They are stellate with truncated tips. Cloacal aperture rather small and roundish. Zooids ca. $1 \mathrm{~mm}$ in length. Branchial aperture 6-lobed; atrial aperture large and does not form a siphon or an orifice. Rows af stigmata 4. Stomach large and slightly longer transversely than antero-posteriorly, and with smooth surface. Anus situated at the level between the $3 \mathrm{rd}$ and 4 th stigmata rows. Gonal not developed in any zooid.

Two species of Didemnum are known from the Japanese waters, namely $D$. japonicum HeRDMAN) found from the bottom off Kôbe and D. album (OKA, MS describe 1 insufficiently in the "Illustrated Encyclopedia of the Fauna of Japan". Although the present specimen resembles both of these species, it approaches more closely, especially in the appearance of the spicule, the specimens of $D$. moseleyi (HERDMAN) which I collectel in the South Seas. At any rate, it is very difficult to classify specimens of Didemnum, and this identification is rather provisional. 


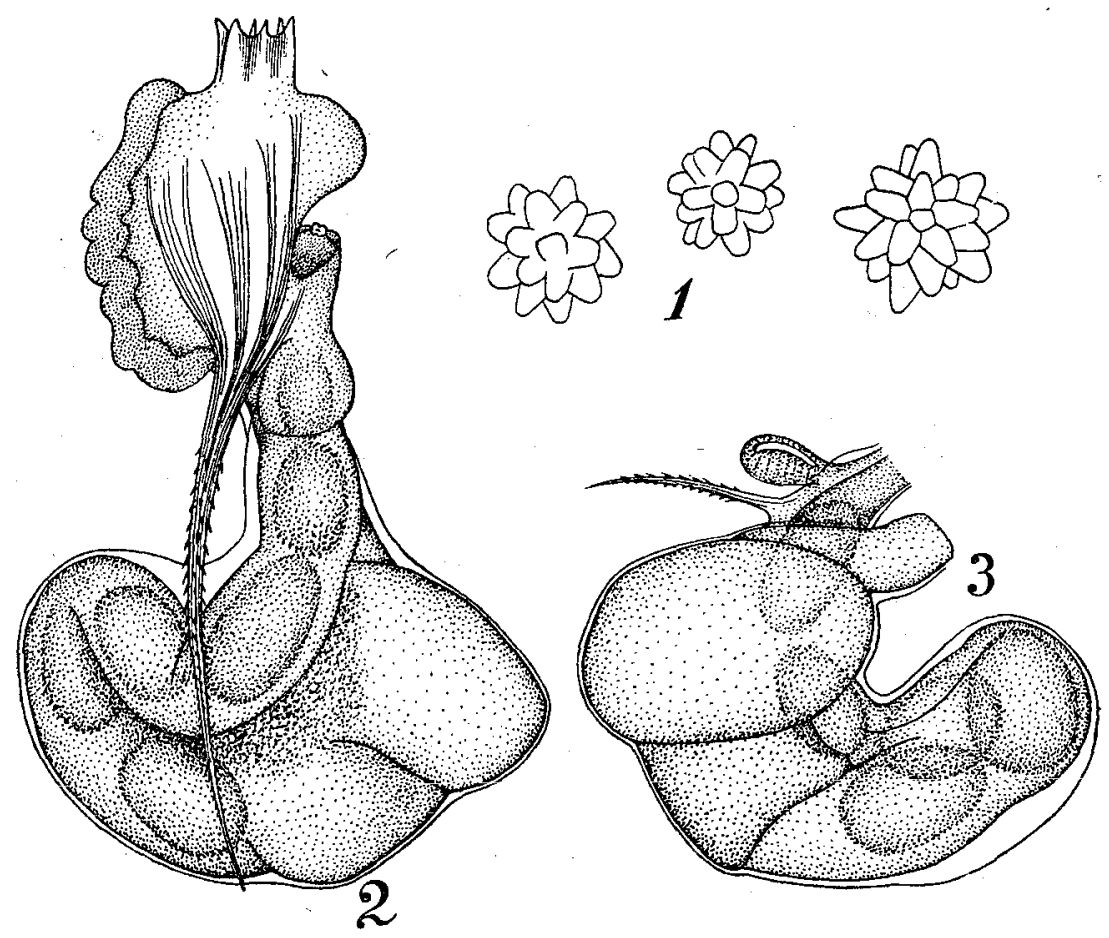

Fig. 3. Didemnum moseleyi (Herdman). 1-.....Calcareous spicules, $\times 270 ; 2 \cdots$. Left side of zooid, $\times 90 ; 3 \cdots \cdots$ Right side of alimentary canal, $\times 90$.

\section{Leptoclinum macrolobium n. sp.}

(Fig. 4)

Five small $(10 \times 3-5 \mathrm{~mm})$ colonies were found on Pseudodistoma antinboja. Test very soft, trazslucent, and scattered in some specimens with many whitish spots which are globular aggregates of minute granules of the size of blatder cells.

Zocids: About $1 \mathrm{~mm}$ in length, embedded in the test without any definite system. Mantle of thorax whitish, and so feeble as that a zooid can hardly be taken out of the test without giving severe injury to the mantle. Usually, the zooids when removed from the test, become completely devoid of the thoracic mantle. Abdomen clothel with a dark violet mantle which colour being especially deep along the alimentary canal, and somewhat lighter on the gonad. Two buds, a large one, ruliment of thorax, and a smaller one, that of abdomen, are attached to the oesophagus. 
Thorax: Branchial aperture 6-lobed. Lobes very large and deeply cut in between each pair so that the aperture assumes a form of a flower, the part between the petals is coloured purple-brown. Tentacles 12; large and small ones being alternately arranegd. Branchial sac with four stigmata rows, each row consisting of 8-10 elongate stigmata. Dorsal languets very long and slender.

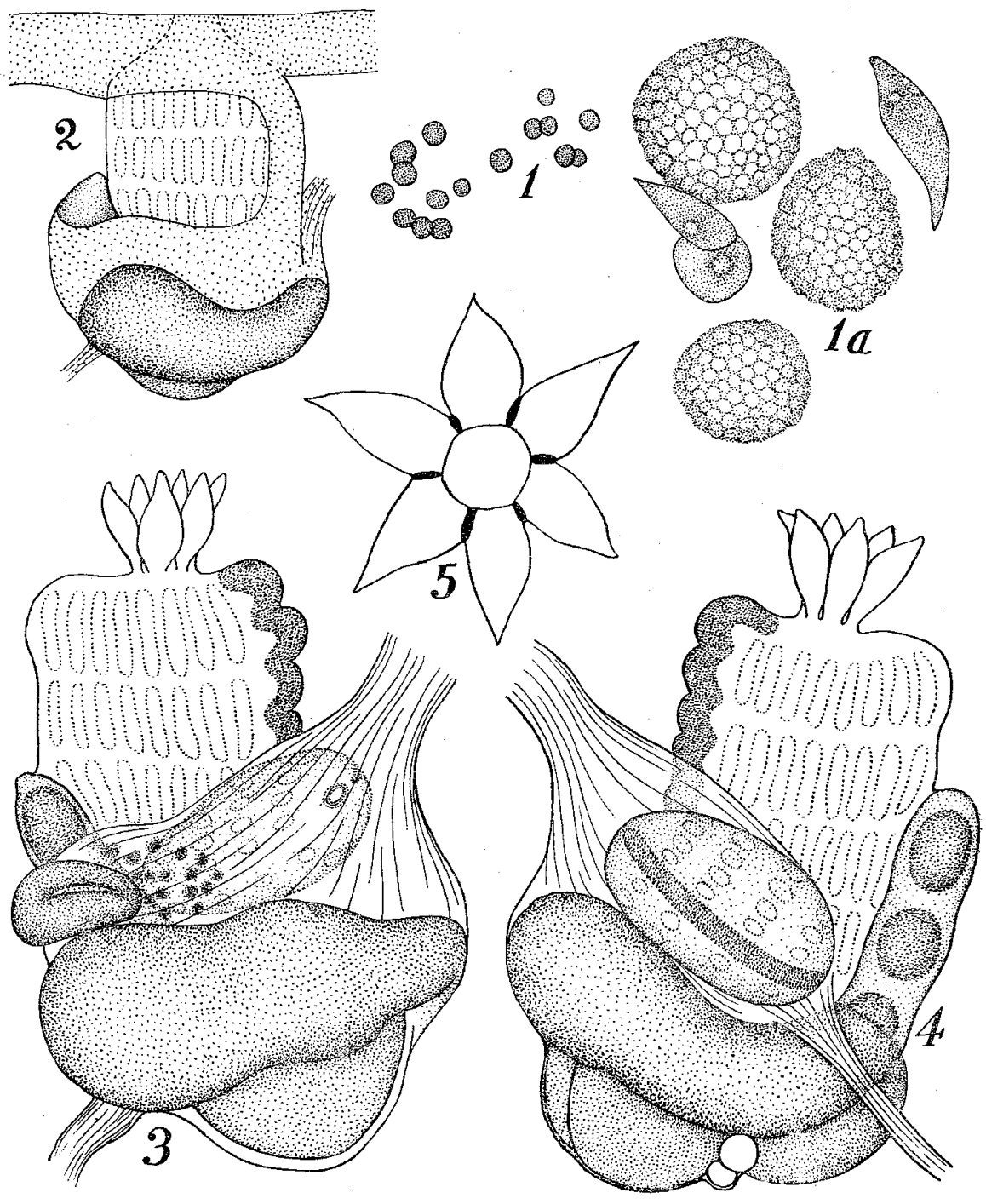

Fig. 4. Leptoclinum macrolobium n. sp. 1…. Whitish globular bodies in the test, $\times 200 ; 1 \mathrm{a} \cdots$. do $\times 1.200 ; 2 \cdots$. Schematic figure of a zooid ; $3 \cdots \cdot$. Right side of zooid; $4 \cdots \cdots$. Left side of zooid, $\times 75$; $5 \cdots .$. . Lobes around the branchial aperture. 
Ciliatel groove is a small elliptical transverse orifice.

Abdomen: Alimentary canal configuration courses as in many species of the genus. Testis consists of two globular follicles. Two masses of strong bandlike tissue and the attached to the zooid at the position between the thorax abdomen, hold the zooils firmly in the test. Many whitish globular boties are contained in these bands as in the surface layer of the test and the mantle of the thorax. Anal opening present near the middle on the dorsal side of the branchial sac; its margin is thickenned, but does not form any lobe.

Remarlcs: The presence of six extraordinarily large lobes around the branchial aperture is the striking characteristic of this now species. Many copepods belonging to the family Harpacticiciae were found clinging to the surface of the colony. It is quite unknown, however, whether the life of this copepod is in any way correlated with that of the ascidian.

5. Syndiazona grandis OKA 1926.

(Fig. 5)

Syn. : Aphanibranchion japonicum 0KA 1906.

cit.: Annot. Zool. Jap. . Vol. 5, pp. 222-265, 1906.

Proc. Imp. Acal., Vol. 9, pp. 223-222, 1933.

This giant compound ascidian is not rave in the vicinity of the Laboratory. There are two specimens of this spesies in the museum of the Laboratory, the larger one consisting of a corona measuring $100 \times 80 \mathrm{~mm}$ in extent and $75 \mathrm{~mm}$ in height, and a peduncle measuring $70 \mathrm{~mm}$ in height. They are grayish brown in colour while in life as well as in the preserved condition. Zooids 30-40 mm in length; large ones may measure $15 \mathrm{~mm}$ in length of the thorax. They are emberder in the test with their ventral sides towards the periphery of the colony.

Thorax: Mantle furnished on each side with 30-40 transverse muscle fibres, while the longitudinal fibres are weak and only a few can be traced on each side. Dorsal tubercle ovate in outline; ciliated groove forming a simple longitudinal slit. Row of dorsal languets considerably displaced on the left side from the dorso-median line. Rows of stigmata ca. 50 in my specimens; longitudinal vessels 26 on one side for an instance; several vessels found near the dorso-median line on the right side are represented by series of small knob-like papillae situated on transverse vessels and provided each with a short protuberance on each of its anterior and posterior sides.

Abdomen: Alimentary canal embedded in compact orange-coloured mesenchyme cells. Stomach situated near the posterior end of the abdomen and elongate in shape. 

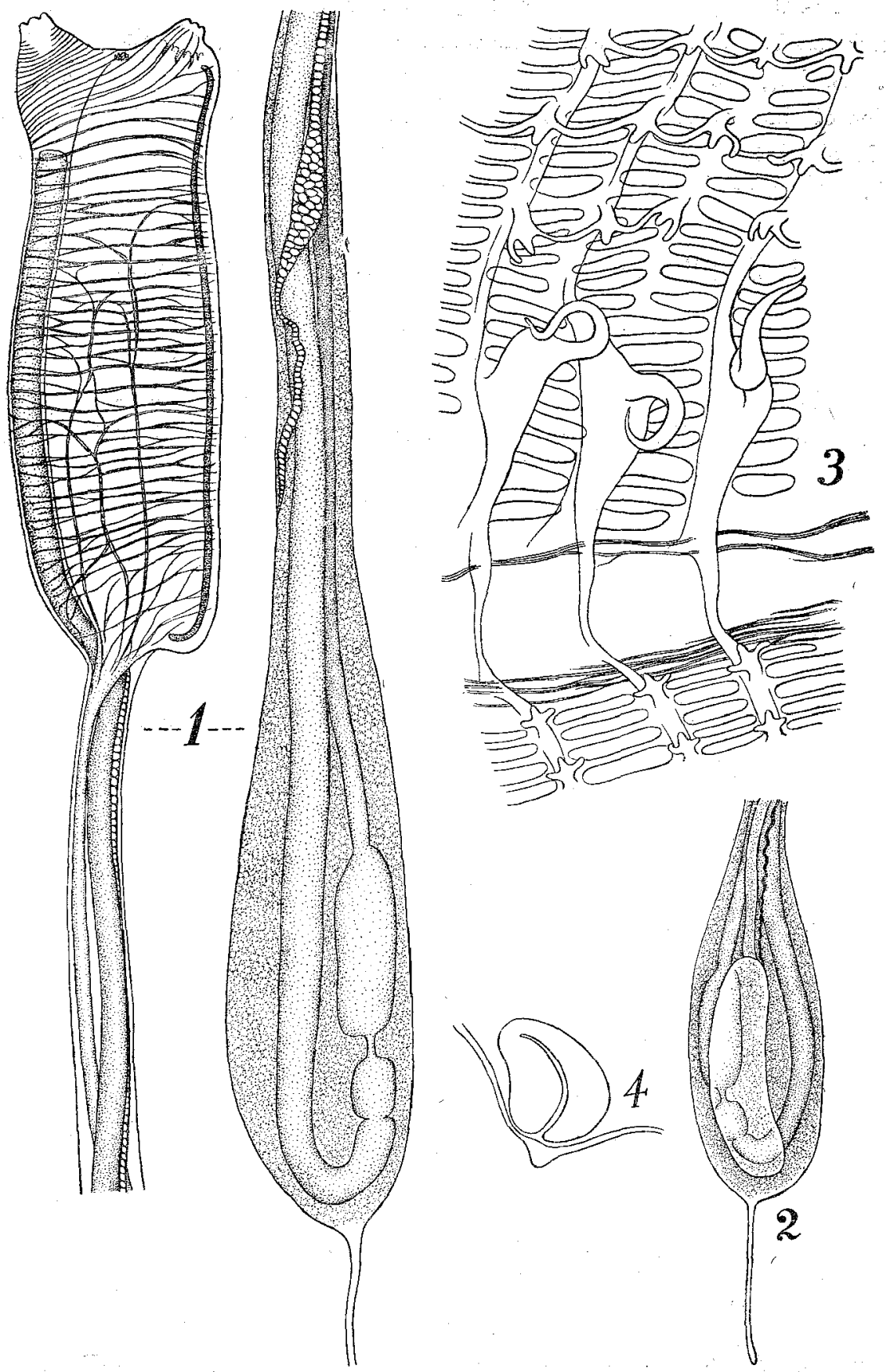

Fig. 5. Syndiazona grandis OKA. 1…Zooid ; $2 \cdots \cdots$ Posterior portion of zooid, showing pericardium; $3 \cdots$... Series of dorsal languets, $\times 55$; 4 .....Dorsal tubercle, $\times 55$. 
Mid-intestine constricted distinctly from both stomach and intestine, the constriction between the mid-intestine and the stomach being especially remarkable. A large elongate pericardium extends from the level of the cardiac portion of the stomach to the posterior end of the abdomen. Anal opening near the level of the 10-14th rows of stigmata; with a smooth but somewhat thickenned margin.

\section{Syndiazona grandis OKA var. discoides n. var.}

(Fig. 6)

A large discoidal colony, $110 \mathrm{~mm}$ in rlameter and $35-40 \mathrm{~mm}$ in thickness, is preserved in the Laboratory. Zooid embetded in the upper layer of colony,
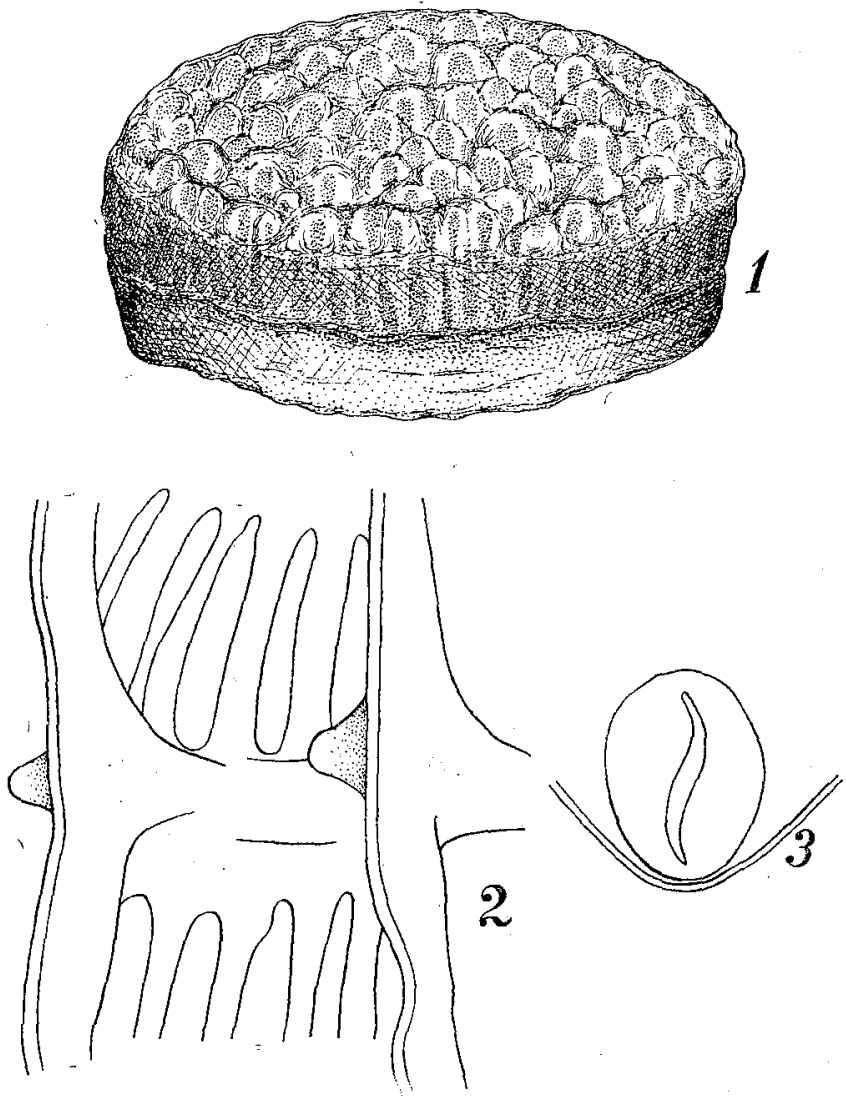

Fig. 6. Syndiazona grandis OKA var. discoides 11. var. 1......Entire colony ; $2 \cdots \cdots$ A part of the branchial sar, $\times 200 ; 3 \cdots \cdots$ Dorsal tubercle. 
ca. $20-25 \mathrm{~mm}$ in thickness, which is pale grayish-brown in colour and semitransparent. The basal portion of the colony is somewhat whitish and quite opaque. Zooids ca. $20 \mathrm{~mm}$ in length and brownish in colour. Branchial aperture 5- or 6-lobe1, atrial aperture 6-1obed. At least 60 transverse muscle fibres are counted on thorax. Tentacles composel of 5 large, 7 small and several minute ones. Branchial sac provided with about 60 rows of stigmata; 27 longitudinal vessels are counted on one side in a zooid. $3-5$ stigmata are present between each pair of logitudinal vessels which are supported on the inner surface of the branchial sac by thin membranes, and each has a knob-like papilla at every intersection with transverse vessel. In the typical form, the longitudinal vessel is not supported by a membrane, but assumes a thread connecting papillae on transverse vessels longitudiually. This difference in the appearance of the longitudinal vessel and the shape of the colony are the most striking characteristics of this new variety.

\section{Symplegma reptans (OKA 1927).}

(Fig. 7; Pl. VIll, fig 2)

I intend to relescribe here the present species which was described incompletely by OKA in the "Illustrated Encyclopelia of the Fauna of Japan" under the name of Synstyela reptans $0 \mathrm{KA}$ (MS). Several large colonies, $60 \times 100$ $\mathrm{mm}$ in extent, were found in April 1940 on a glass plate immersed for test of a kind of ship paint. Test thin and transparent. Vessels running through the test are crowded densely near the periphery of the colony. They form elongate blind sacs here and there in the test, especially along the periphery of the colony, which contain many yellowish corpuscular buds. Zooid looks translucent, because of the presence of a few yellowish pigment cells in the mantle. Another example was obtaind by Mr. URA of the Laboratory in October 1948 from the surfare of Styela plicata which is the commonest ascidian in this region. Test thin and trausparent, but very strong. Zooids elliptical and $1.5 \times 2.5 \mathrm{~mm}$ $\sim 2 \times 3 \mathrm{~mm}$ in size. They show considerable individual colour variation, ranging from conspicuous vermilion to almost colourless state. Almost invariably, however, the mantle is coloured deeply on each side between the branchial and atrial apertures. Branchial aperture situated near the anterior end of the body, while the atrial aperture is found nearly in the middle of the boty which is strougly compressed dorso-ventrally. Both apertures are fringed with smooth margins. Fine atrial tentacles are discernible in some zooids.

Branchial sac: 7 rows of stigmata on the dorsal side and 8 (rarely 9) on the ventral side; the anterior-most row on the dorsal side divided into two rows on 


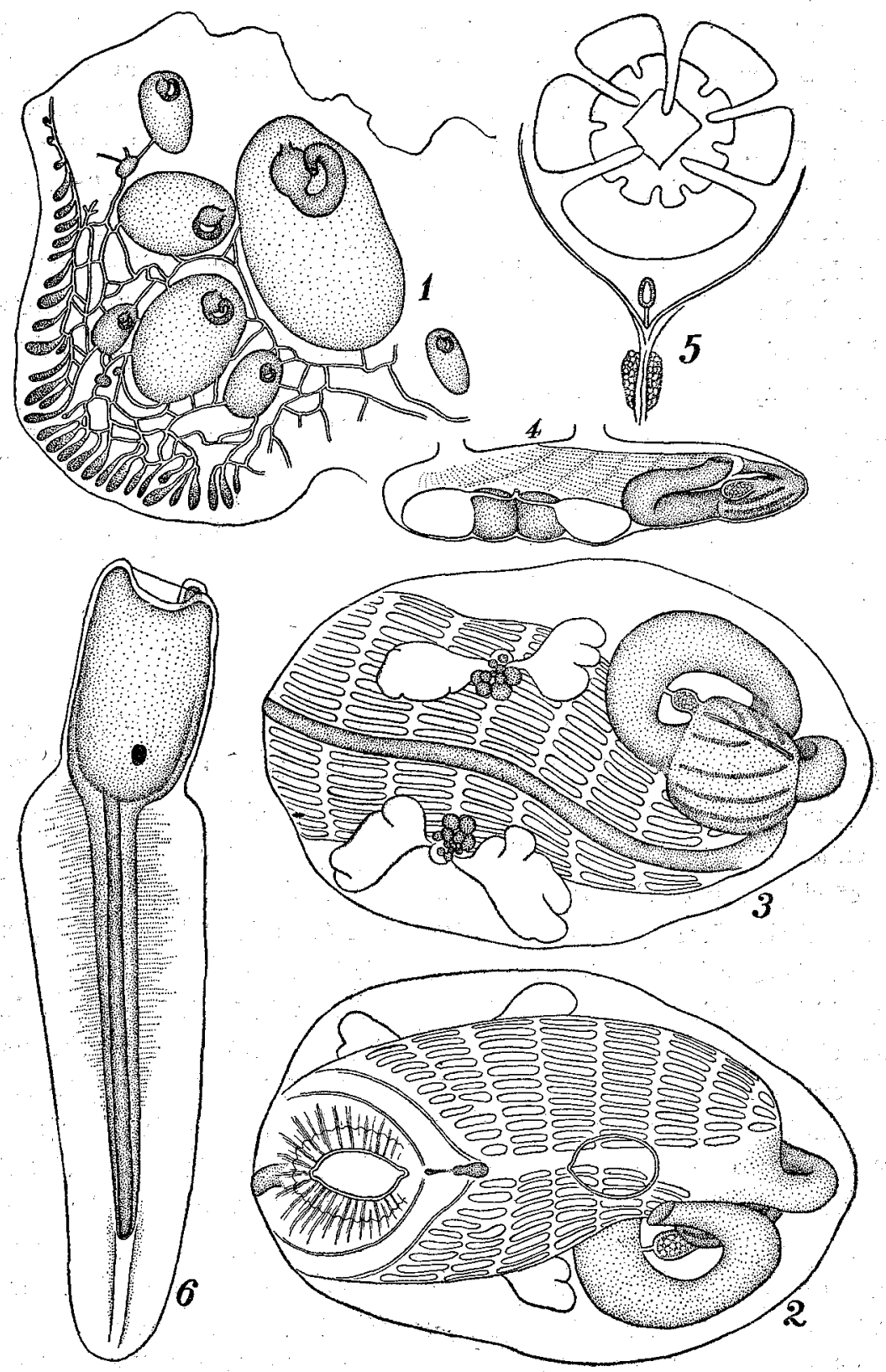

Fig. 7. Symplegma reptans (OKA) 1…A part of colony, $\times 10$; $2 \cdots \cdots$ Dorsal side of zooid, $\times 20,3 \cdots \cdots$ Ventral side of zooid, $\times 2 \mathrm{~J}$; $4 \cdots$... Left side of zooid, $\times 13 ; 5 \cdots$. Tentacles and ciliated groove ; 6......Larva, $\times 60$. 
the ventral side. 3-4 4-5 elongate stigmata are present between each of four longitudinal vessels. Parastigmatic vessel absent. Tentacles 12 in all, 5 large and 7 small ones are arranged as shown in the figure. Ciliated groove is a small elliptical orifice situated longitudinally. Dorkal lamina is a plain membrane.

Alimentary system: Alimentary canal situated on the ventral side in the left posterior quater of the body. The anterior end of the intestinal loop does not reach the middle of the zooid. Stomach is about one-half as long as the mass of the alimentary canal and provided with about 10 longitudinal folds on the surface. A prominent caecum is present on the inner pyloric corner of the stomach and connected to the intestine by a thin vessel. Intestine figures roughly a circle; margin of the anus is smooth.

Gonad: A pair of gonads are developed in the anterior half of the body. Each consists of a pair of testicular lobes and several, up to 6 , ova embedded between these lobes which are cut in slightly at several points along the margins. Fertilized ova develop to tadpole larvae in the cavity of the zooid.

Remarks: Two ascidians akin to the present species are known from the waters outside Japan. One is Sympiegma viride HERDMAN of the New World, which has many more (24) branchial tentacles and 13-14 rows of stigmata. The other is Botryllocarpa viridis (PIzon) from Amboina, which has a structure quite close to that of $S$. reptans, except the number of the longitudinal vessels of the branchial sac being only three as far as known in the specimens of Pizon.

\section{Symplegma connectans $\mathrm{n}$. sp.}

(Fig. 8)

A small colony, $20 \times 15 \mathrm{~mm}$ in extent, was taken from the surface of Pyura michaelseni var. depressa. Test thin and transparent. Zooids as large as in the preceding species. Mantle of preserved specimen opaque and dark brownish in colour. The zooids are nearly the same in structure as those in $S$. reptans, except the following points: 1...Intestinal loop reaches anteriorly beyond the middle of the zooid. $2 \cdots A$ short reddish vessel is present in place of the pyloric caecum in $S$. reptans and bridges the space between the inner pyloric cormer of the stomach aud the intestine. A reddish orange glandular tissue, probably the circum-intestinal gland, is well developed on the second course of the intestine. There are more (14) longitudinal folds on the stomach than in S. reptans. $3 \cdots$ Branchial tentacles 8,3 large +3 medium +2 small ones for an instance. Atrial tentacle can not be detected. probably on account of the contraction of the body. 4...Rows of stigmata are 8 on the dorsal side, and 11 on the ventral side. 


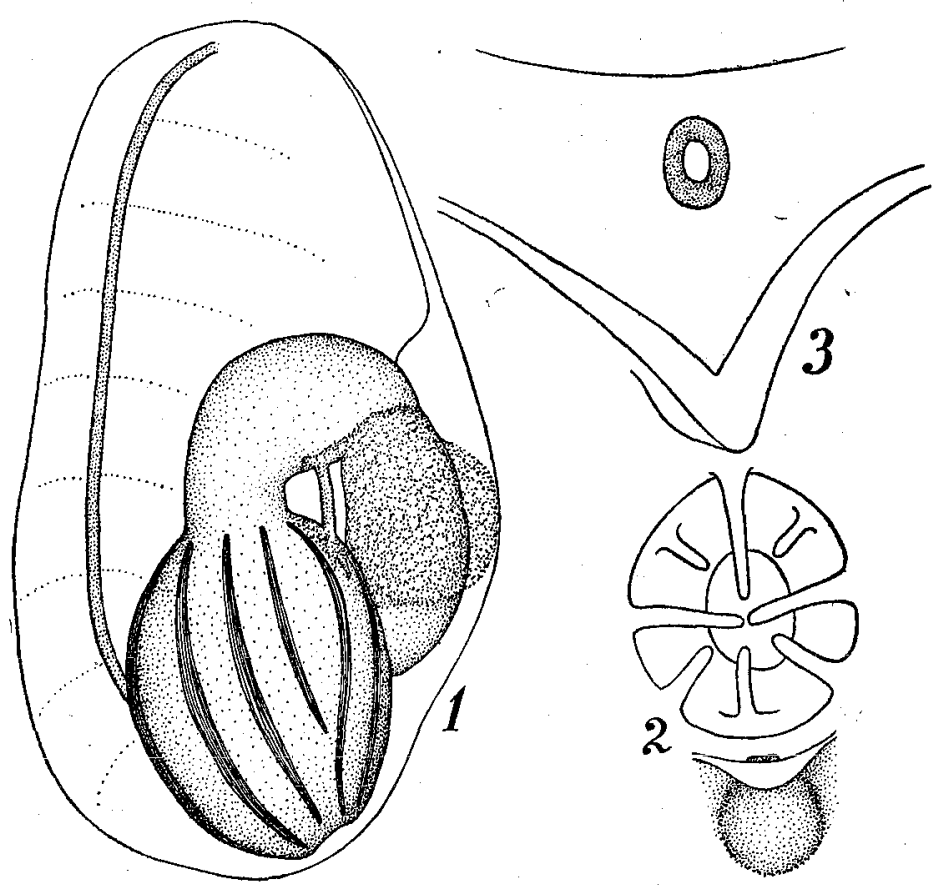

Fig. 8. Symplegma connectans n. sp. 1….Zooid from ventral side, $\times 25 ; 2 \cdots \cdots$ Branchial tentacles and dorsal ganglion; $3 \cdots \cdots$. Ciliated groove, $\times 20$.

The colony contains no mature zooid. The species is named in reference to the presence of a vessel connecting the imner pyloric corner of the stomach with the intestine.

\section{Styela esther HARTMEYER 1906.}

(Fig. 9)

Two spesimens were found among the bottom samplles collected by Prof. MIYADI and the late Mr. Masui in Tokyo Bay. The larger one is $45 \mathrm{~mm}$ and the smaller one is $40 \mathrm{~mm}$ in length. They were lying on gravels or shell fragments by the left side of the boly. Test leathery and coloured dark brown and marked with a few grooves and foldings on the right and dorsal side which is free. Branchial aperture present at the anterior end of the body, atrial aperture near the middle on the dorsal side. Both siphons inconspicuous. Test about $1 \mathrm{~mm}$ in thickness, with the inner surface glistening and grayish brown in colour. Mantle thin and dark brown. Muscles arranged in a coarse 
network. Branchial siphon terminal, atrial siphon present near the middle on the dorsal side. Both siphons are 4-lobed, and provided with a series of curious 3 elevations between the bases, just opposite the dorsal ganglion.
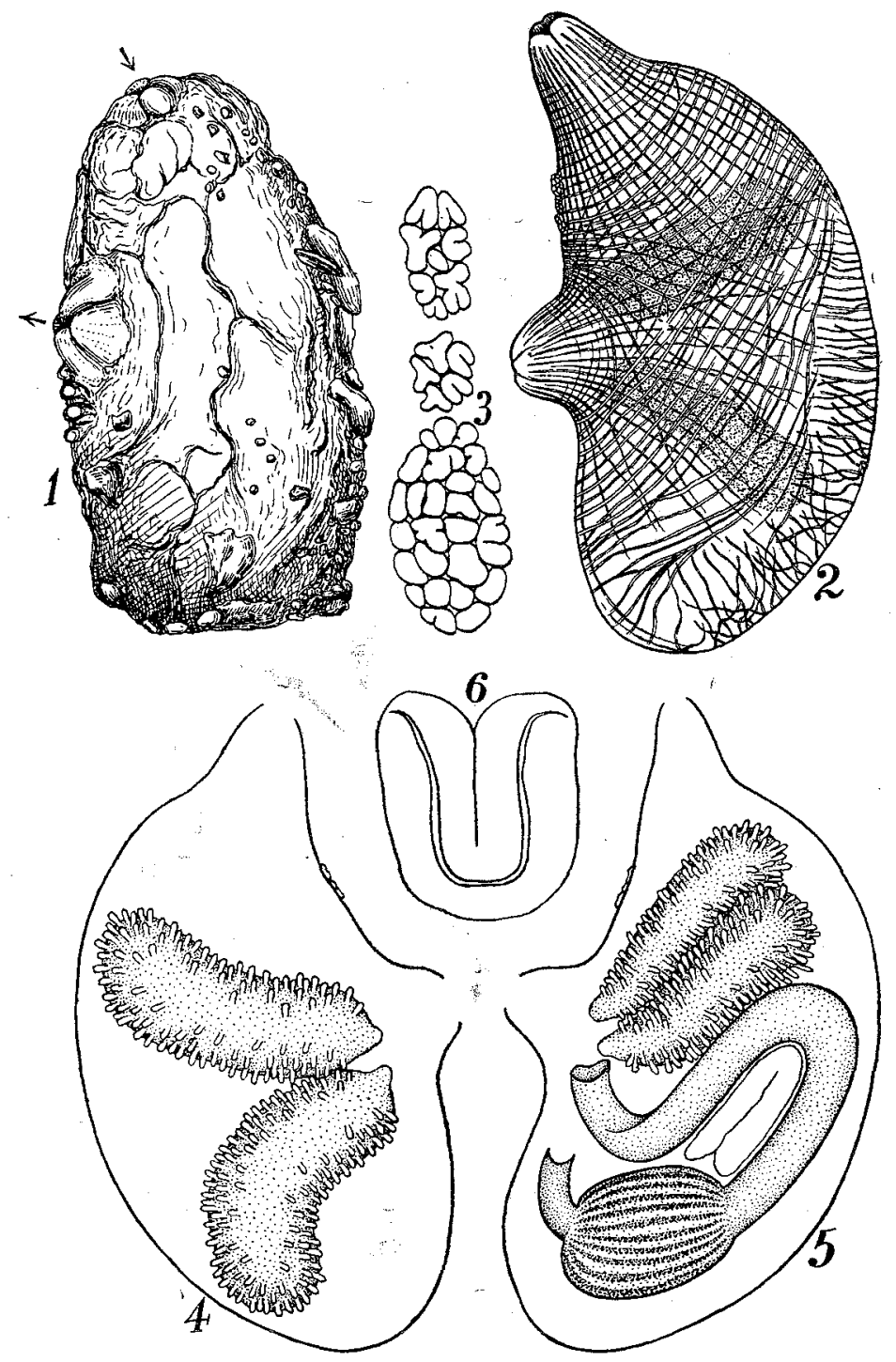

Fig. 9. Styela esther HARTMEYER. 1…..Entire animal ; 2..... Mantle body, right side; $3 \ldots .$. Series of elevations between apertures; 4 ..... Right half, from inside ; 5 ...... Left half, from inside ; $6 \cdots . .$. Dorsul tubercle. 
Branchial sac: Longitudinal vessels arranged as follows:

Specimen. 1 (45 $\mathrm{mm}$ long)

Specimen $2(40 \mathrm{~mm}$ long $)$

left $\quad$ D. $8(9) 5(14) 6(14) 7(11) 5 \mathrm{~V}$.

left $\quad$ D. $14(11) 4(15) 5(15) 5(12) 5 \mathrm{y}$

right D. $7(7) 5(15) 5(14) 5(12) 5 \mathrm{~V}$.

right D. $10(9) 6(13) 5(13) 5(12) 5 \mathrm{~V}$.

10-15 thin transverse vessels are present letween each pair of thicker vessels in the middle portion of the branchial sac. Stigmata elongate, ca. 10 in each mesh. Parastigmatic vessels detected. Tentacles about 30, arranged roughly in the scheme: large-small-medium-small-large $\cdots$. Ciliated groove simple and $U$ shaped.

Alimentary system: Alimentary canal describing a simple U-sbaped course; the distal portion of rectum proceeds dorsally a short distance. Oesophagus short, stomach with about 10 longitudinal striations on the inner surface. Anal margin smooth. Two large elongate endocarps fill the intestinal loop completely.

Gonad: Two elongate gonads are present on each side, each consisting of a median ovary and many testicular follicles arranged along the margin of the ovary. The specimens describel by OKA from Mutn Bay bear 2-3 gonats on each side of the body.

Remarks: In HARTMEYER's specimens from Sagami Bay, the surface of the stomach is described as smooth. It is, however, highly probable that the striation or the folding on the stomachal wall had been obliterated according to the condition of preservation. Styela partita STIMPson, found by OKA near Yokohama, was also provided with two gonads on each side, although their arrangement and the course of the alimentary canal were quite different. It is noteworthy that both the specimens described here harboured many amphipods in their boly cavities, 55 in the larger specimen and 27 in the smaller.

\section{Pyura michaelseni (OKA 1906).}

(Fig. 10; Pl. VIII, fig. 3)

The structure of this common species is described in detail by OKA in Sci. Rep. Tôhoku Imp. Univ., Vol. 10, pp. 437-439, 1935. I intend to record here some remarks on some of the specimens from the vicinity of Seto.

The branchial siphon situated about $1 / 4$ of the body length from the anterior end, the atrial siphon slightly behind the middle on the dorsal side. Both siphons are armed on the inner surface with many minute spines as shown in the figure. The liver is divided into a number of nuequal lobes, andcolonred a reddish brown in some specimens. The difiused portion of the gonad is coloured vermilion.

The gonad on the right side is situated considerably apart from the hypobranchial 


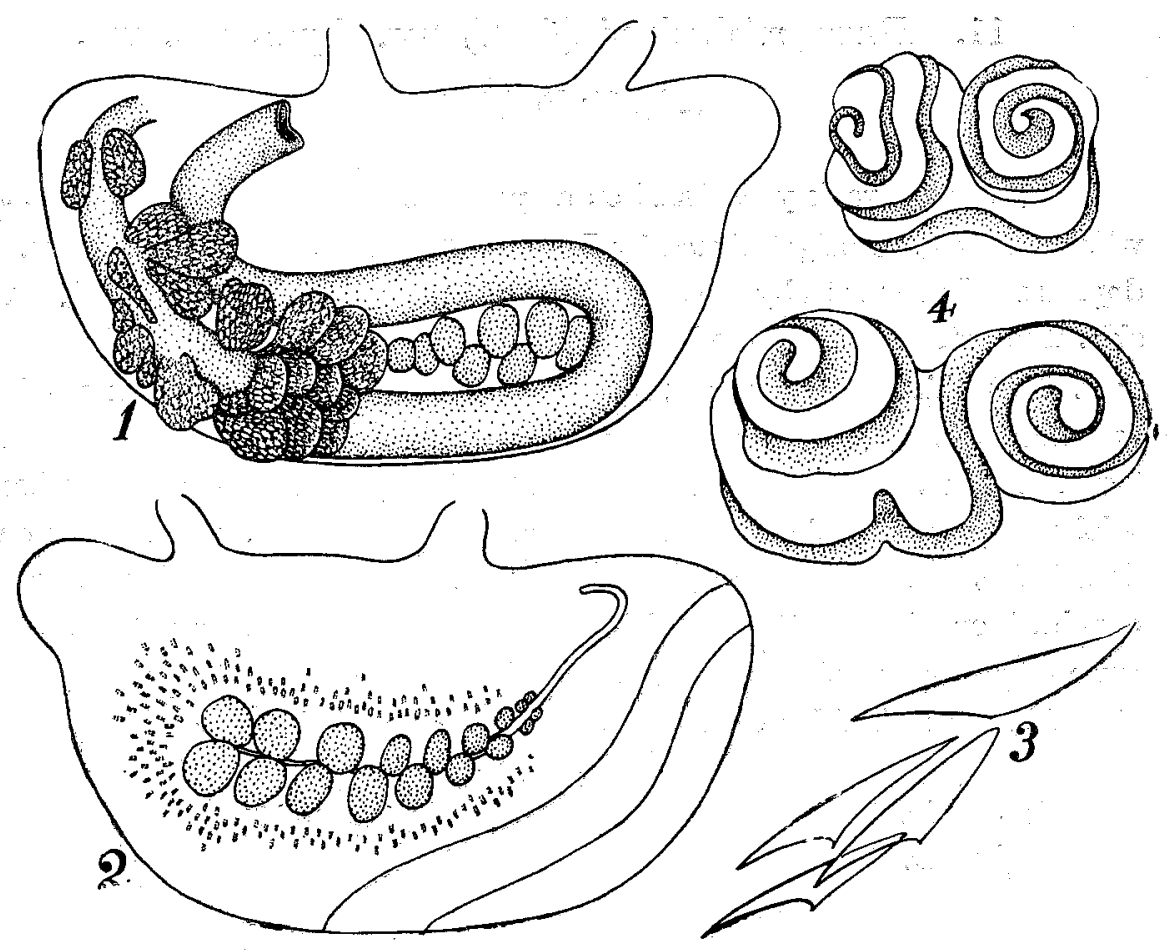

Fig. 10. Pyura michaetseni (OKA) 1…Left half, from inside; $2 \ldots \ldots$ Right half, from inside; $3 \cdots . .$. Spinules on the inner surface of the siphon, $\times 200 ; 4 \cdots \cdots$ Dorsal tubercle.

vessel. The intermediate longitudinal vessels are much fewer in Seto specimens than in that of Mutu Bay.

Specimen 1 (36 $\mathrm{mm}$ long)

$$
\begin{array}{ll}
\text { left } & \text { D. } 3(17) 4(18) 4(20) 5(18) 5(18) 4(13) 4 \mathrm{~V} . \\
\text { right } & \text { D. } 4(15) 3(20) 4(20) 4(20) 4(18) 6(15) 4 \mathrm{~V} .
\end{array}
$$

Specimên 2 (45 $\mathrm{mm}$ long)

$$
\begin{array}{lllll}
\text { left } & \text { D. } 3(20) 3(21) & 3(22) & 4(20) 4(20) 3(17) 4 \mathrm{~V} \\
\text { right } & \text { D. } 3(21) 3(20) 3(23) 3(21) 3(20) 4(19) 4 \mathrm{~V} .
\end{array}
$$

This difference seems to be due to the difference in size of the animals which are rather small, being $30-50 \mathrm{~mm}$ in many cases, as compared with the specimens found in Mutu Bay which may be as large as $90 \mathrm{~mm}$. 


\section{Pyura michaelseni (OKA) var. depressa n. var.}

(Fig. 11; P1. VII, fig. 4)

This new variety is based on a spesimen, $48 \mathrm{~mm}$ in length $\times 32 \mathrm{~mm}$ in width $\times 28 \mathrm{~mm}$ in height, found by Dr. SHIINo at Sugasima, Prov. Sima. It is depressed dorso-ventrally and attached to the substratum by its whole ventral side. The anterior part of the body is compressed more strongly than the posterior part. Test thick and leathery; its surface smooth and whitich except in the central portion on the dorsal side, where it is wrinkled considerably around two apertures. The inner surface is whitish except in the neighbourhood of 4-lobed apertures coloured violet-brown. Mantle yellowish white, thick on the dorsal side, and very thin on the ventral sire. Siphons situated roughly at each one-third on the length of body, are tinted violet-brown on the tip. Sparse muscles present on the dorsal side.

Brancrial sac : Six folds on each side. Longitudinial vessels arranged as follows:

left $\quad$ D. $4(18) 3(20) 3(20) 5(18) 3(17) 4(12) 4 \mathrm{~V}$.

right D. 5 (18) 3 (19) 3 (22) 3 (19) 3 (19) 3 (16) $3 \mathrm{~V}$.
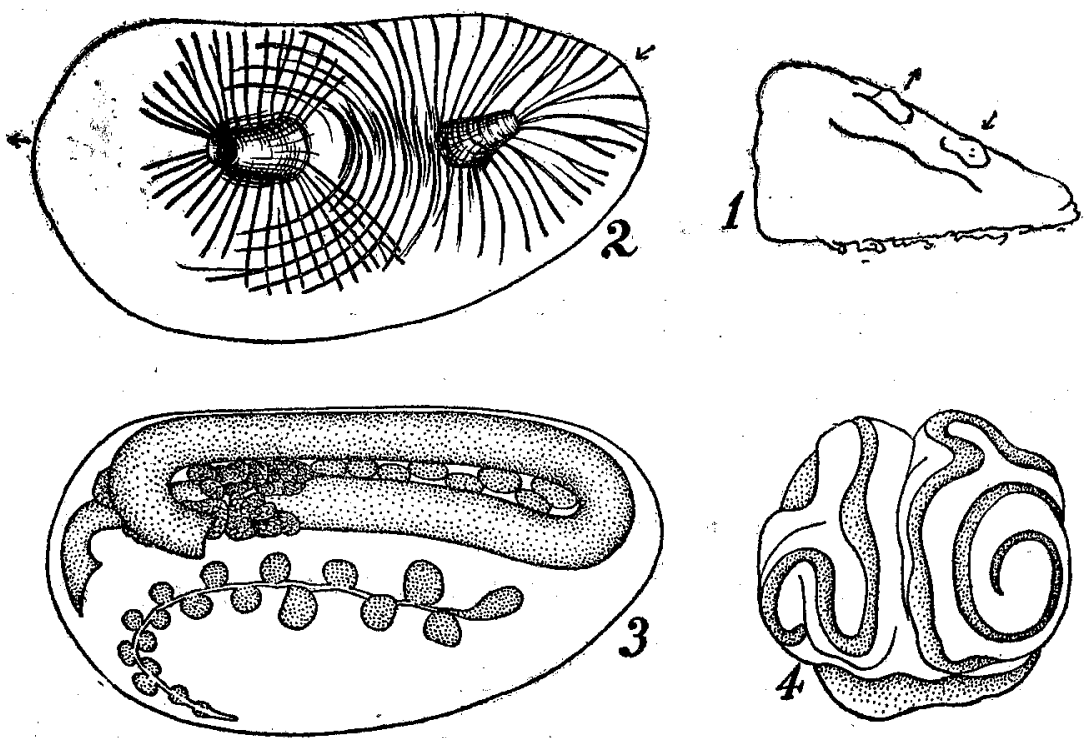

Fig. 11. Pyura michaelseni (OKA) var. depressa n. var.

1......Entire animal, right side; 2..... Dorsal side of mantle body;

$3 \cdots .$. Ventral half, from inside; $4 \cdots \cdots$. Dorsal tubercle, $\times 50$. 
Large and small transverse vessels arranged alternately near the middle of the branchial sac. About 5 elongate stigmata in each mesh. Parastigmatic vessels always present. Tentacles 16, comprising large and small ones beside a considerable number of minute ones; branches in 2 orders. Dorsal tubercle rosette as in Pyura michaelseni.

Alimentary system : Alimentary canal figures a narrow loop in the left half of the ventral side. In structure it is the same as in the preceding species. Liver yellowish.

Gonad : As in P. michaelseni, in flesh colour.

Remarks. This variety is distinguished from the type from by its dorso-ventrally depressed form, whitish test, and by the absence of minute spines on the inner surface of the siphon. Otherwise it is nearly identical with $P$. michaelseni. No intermediate form with respect the features mentioned above has been found. So I prefer to treat the present specimen as a variety of $P$. michaelseni.

\section{Pyura masuii n. sp.}

(Fig. 12)

Three specimens were found among the bottom samples collected by Prof. MryAd and the late Mr. MASu in Tokyo Bay. The animal closely resembles Pyura michaelseni. It is grayish red in colour and coverel with gravels and shell fragments all over, except the elongate dorso-central area. The apertures are situated one at each end of this area and surrounded by several lobes; the lobes around the atrial aperture are projected into small finger-shaped prominences. The animals seems to lie with the ventral side downwards. Mantle reddish brown; muscles only on the dorsal side. Siphons 4-lobed, and situated one at each terminus of the middle third on the dorsal side. Minute spines absent from the inner surfase of the siphon. Many minute tentacular prominences present on the surface of the atrial cavity which is bordered with a conspicuous atrial velum near the base of the siphon, and also on the surface of the dorsal part of the branchial sac.

Branchial sac : 6 folds on each side. Longitudinal vessels arranged as follows: Specimen 1 (35 $\mathrm{mm}$ long)

$$
\begin{array}{lll}
\text { left } & \text { D. } 4 \text { (15) } 3(17) 4 \text { (17) } 4 \text { (17) } 4 \text { (17) } 4 \text { (17) } 4 \mathrm{~V} \text {. } \\
\text { right } & \text { D. } 4 \text { (16) } 3 \text { (17) } 3 \text { (20) } 3 \text { (18) } 5 \text { (15) } 5 \text { (12) } 4 \mathrm{~V} \text {. }
\end{array}
$$

Specimen 2 (30 $\mathrm{mm}$ long)

$$
\begin{aligned}
& \text { left D. } 3(16) 2(17) 3(17) 4(16) 4(15) 4(12) 5 \mathrm{~V} . \\
& \text { right D. } 3(15) 2(20) 3(17) 3(15) 4(14) 5 \mathrm{~V} . * \\
& \text { (* } 6 \text { folds are present in the anterior part of the branchial sac.) }
\end{aligned}
$$




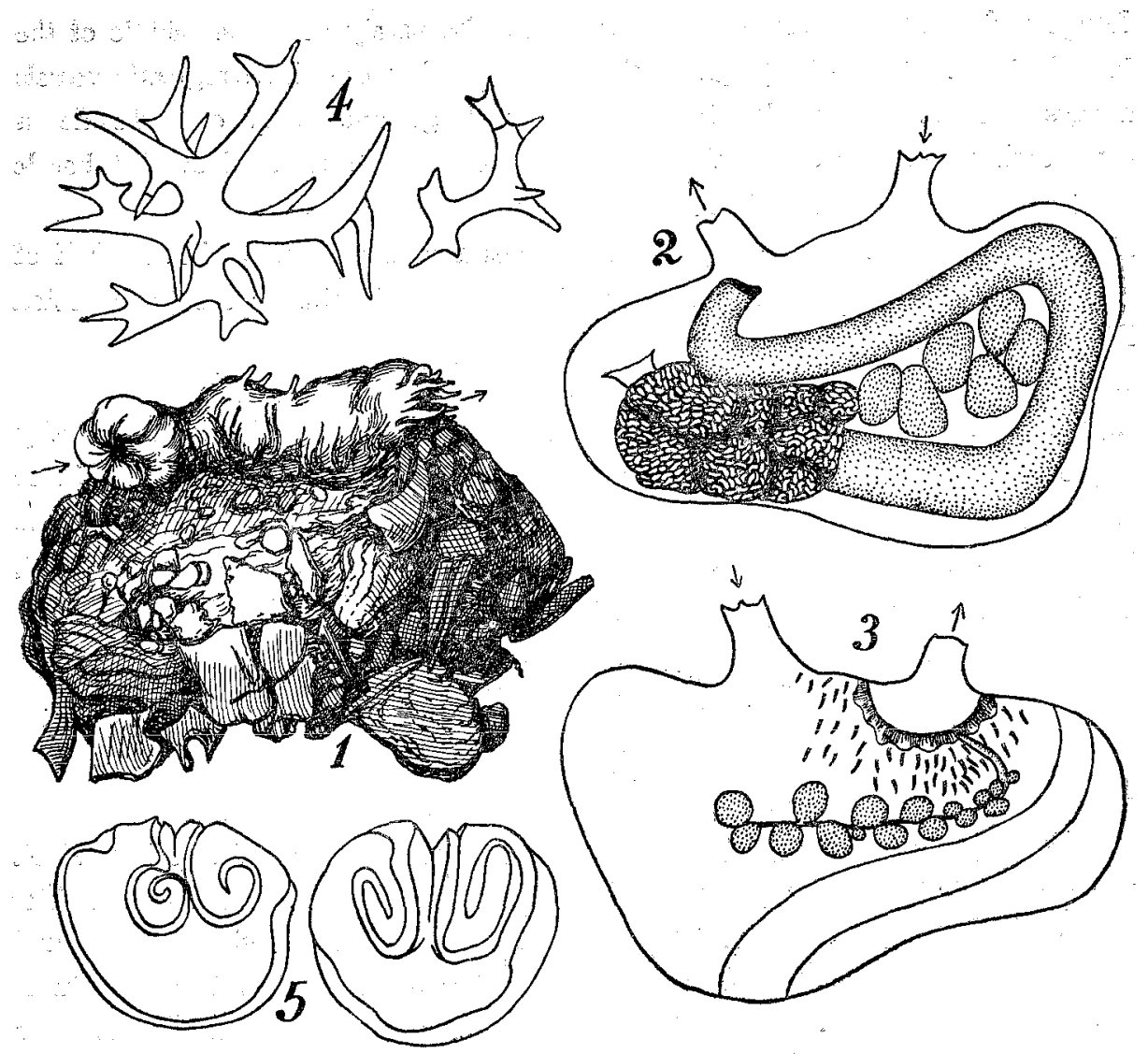

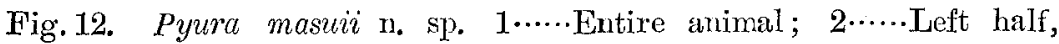
from inside; $3 \cdots \cdots$. Right half, from inside; $4 \cdots \cdots$. Spicules, $\times 200$; 5......Dorsal tubercle.

3-5 smaller transverse vessels between each pair of larger vessels found in the middle portion of the branchial sas. Stigmata number 5-8 in eash mesh. Parastigmatic vessels always present. Tentacles ca. 16, arranged in the scheme: large-small-medium-small-large $\cdots$; branches in 3 orders. Each tentacle sprinkled with minute opaque spots along its whole length. Of tentacles relatively large ones have a few calcareous spicules in their thickened basal portions. Spicules are of complicated horn-shape. Dorsal tubercle consists of two spirals.

Alimentary and reproductive organs resemble closely those of $P$. michaelseni. Liver appears more compact in this species than in $P$. michaelseni. Gonars on the right side are situated very closely to the hypobranchial vessel.

The presence of spicules in tentacles and the absence of minute spines on the inner surface of the siphon are the most striking charcteristics of this new species. 


\section{Pyura vittata (STIMPSON 1852).}

(Fig. 13)

On Japanese specimens of this well-known species, OKA gave detailed descriptions in his two papers $(1906,1935)$. I record here only the structure of the branchial sas of a specimen found by Dr. SHIno at Sugasima.

Specimen of $31 \mathrm{~mm}$ long. Longitudiual vessels :

left $\quad$ D. $3(27) 3(25) 4(27) 5(26) 5(20) 5(13) 3 \mathrm{~V}$.

right D. $3(26) 4(26) 4(28) 5(27) 5(23) 5(13) 3 \mathrm{~V}$.

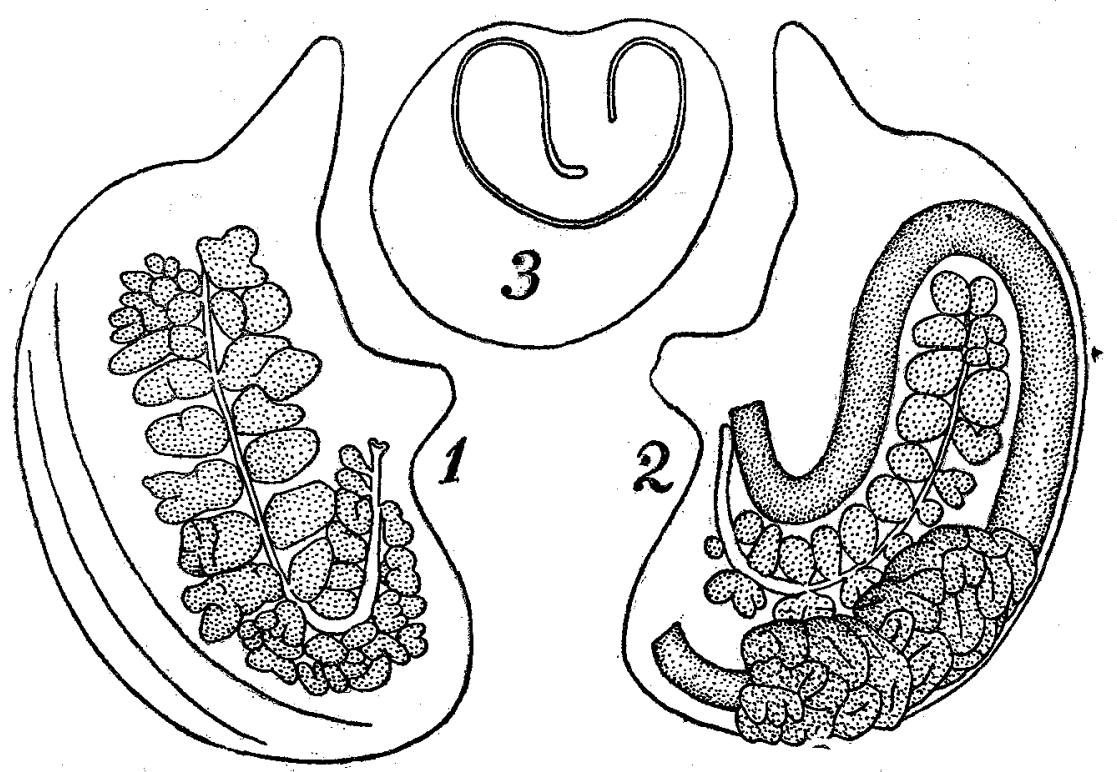

Fig. 13. Pyura vittato (STIMPson). 1….Right half, from inside, 2 ......Left half, from inside; $3 \cdots \cdots$. Dorsal tubercule, $\times 55$.

10-20 small transverse vessels between a pair of larger ones in the central part of the banchial sac. Stigmata elongate, 5-8 in each mesh. Parastigmatic vessels present. Tentacles consist of 13 large and many smaller ones. The Iobation of the suus is very indistinct.

\section{Pyura shiinoi n. sp.}

(Fig. 14)

Two mature mantle specimens were offered to me by Dr. SHIno who 
found them at Sugasima in April 1948. They are flesh in colour. Muscles moderately developed. Branchial aperture subterminal, atrial aperture at about a third of the body length from the posterior end of the body. Each siphon is of a considerable length, four-lobed and reddish in colour. The inner surface of the siphon is red and finely creased, but without any minute spines.

Branchial sac : Seven folds on each side. Longitudinal vessels arranged as follows : -

Specimen 1 (21 mm long)

left $\quad$ D. 1 (20) 2 (18) 2 (17) 2 (21) 4 (17) 3 (17) 2 (11) 1 V.

right D. 1 (16) 2 (17) 2 (22) 4 (23) 3 (21) 1 (17) 1 (10) $1 \mathrm{~V}$.

Specimen 2 (18 $\mathrm{mm}$ long)

left $\quad$ D. 1 (18) $3(18) 3(19) 2(20) 3(20) 1$ (15) 0 (5) 0 V.

right D. 2 (16) 2 (20) 2 (20) 5 (20) 4 (16) 3 (14) 3 (8) 1 V.

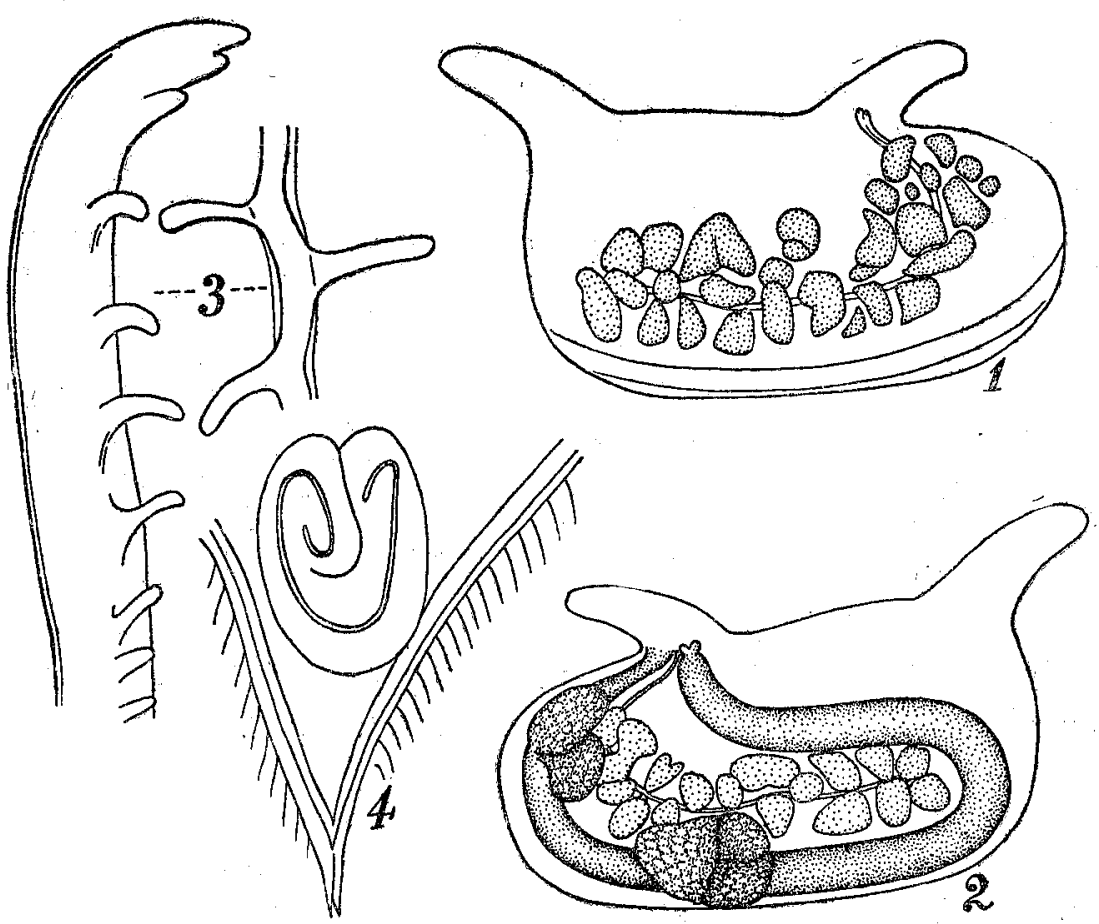

Fig. 14. Pyura shiznoi n. sp. $3 \cdots \cdots$. Right half from inside; $2 \cdots \cdots$ Left half from inside; $3 \cdots \cdots$ Tentacle, $\times 25$; Dorsal tubercle; $\times 50$.

VII is weakly developed in both specimens. 7-10 small transverse vessels between each pair of larger vessels; $3-5$ elongate stigmata in a mesh; parastigmatic vessels are found very sparsely. Tentacles ca. 20, comprising large and 
small ones; branches in 1 order. Dorsal tubercle rather large; ciliated groove horse-shoe-shaped, with curled-in terminals.

Alimentary system : As in common pyurids. Liver, pale yellowish, divided into two groups which are apart widely from each other. Anus bilobed.

Gonad: As in the preceding species.

\section{Herdmania momus (SAVIGNY 1816.)}

(Fig. 15; P1. VIII, figs. 5-6)

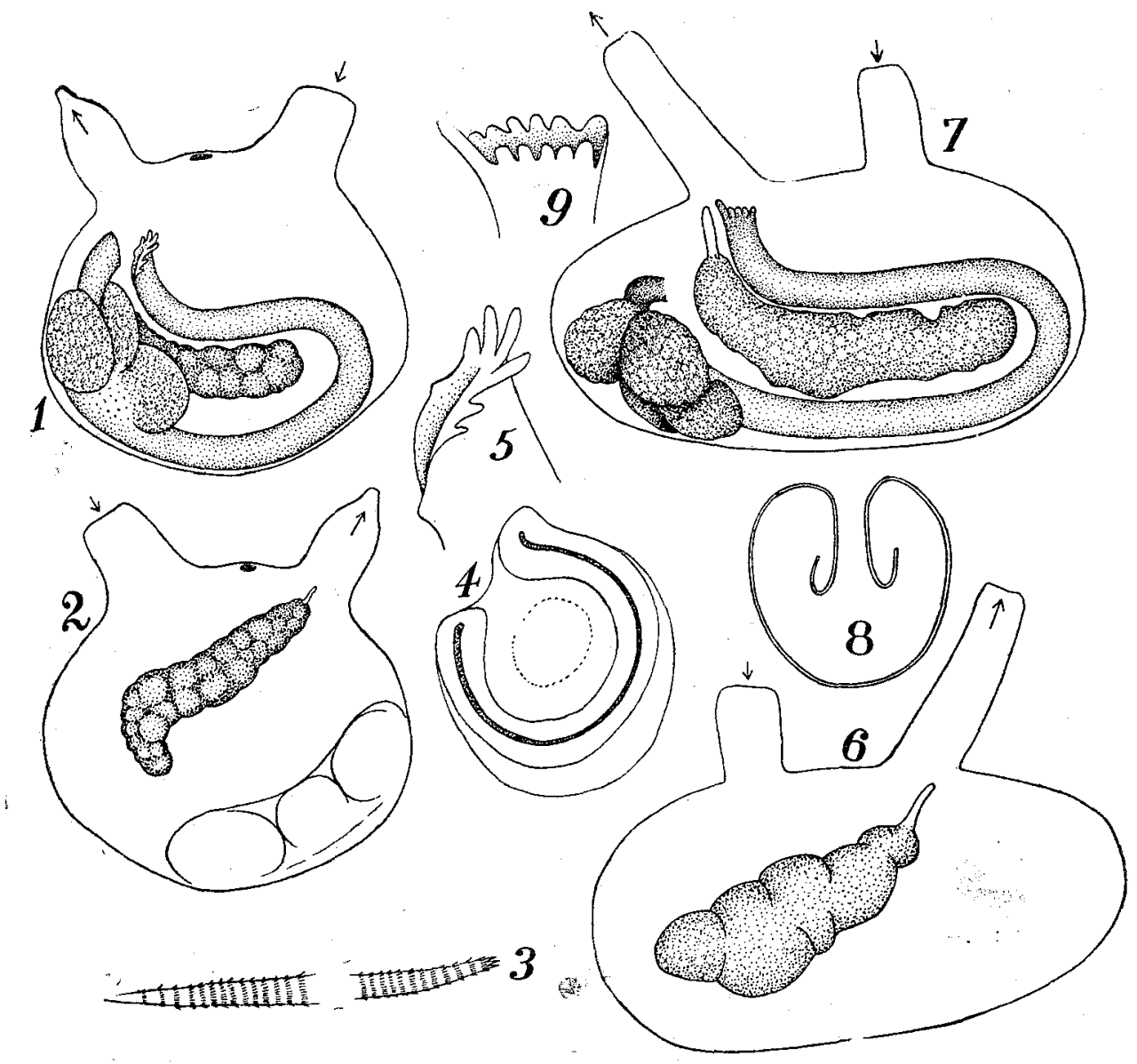

Eig. 15. Herdmania momus (SAvignY , [1-5 A small specimen $(10 \mathrm{~mm}$ long) ] 1..... Left half, from inside; $2 \cdots \cdots$. Right half, from inside; $3 \cdots .$. Spicule, $\times 200 ; 4 \cdots \cdots$ Dorsal tubercule, $\times 75 ; 5 \cdots \cdots$ Anus. $[6-9$ A large specimen $(30 \mathrm{~mm}$ long) $] 6 \cdots$....Right half, from inside; $7 \cdots \cdots$. Left half, from inside; $8 \cdots .$. . Ciliated groove ; $9 \cdots \cdots$. Anus. 
This is one of the commonest ascidians found near the Laboratory. The beautiful reddish body occurs rather often in tide pools from spring to summer. Here I record only the number of the longitudinal vessels of the branchial sac on a small young specimen.

Specimen of $10 \mathrm{~mm}$ long : 8 folds on each side. Vessels arranged in the scheme : - (7) 1 (8) 2 (8) 1 (11) 2 (11) — in the central portion of the branchial sac.

\section{Halocynthia simaensis n. sp.}

(Fig. 16)

One specimen found by Dr. SHrino at Sugasima. The body is roughly elliptical, $50 \mathrm{~mm}$ long, $32 \mathrm{~mm}$ wide and $35 \mathrm{~mm}$ in height. It is attached to the substratum by the ventral side. Many papilla-like adhesive processes are found along the margin of the attachment surface. Test rather thin, but very tough, surface without any deep groove or folding, though somewhat rough. Indistinct apertures situated in the right anterior quarter of the animal and surrounded by several spiny processes. Test reddish in colotur which is deeper on the dorsal side and lighter near the attanment surface; the inner surfare coloured bright red on the dorsal side and yellowish white on the ventral side. Mantle yellow and much thicker on the right side than on the left side. Branchial siphon subterminal, atrial siphon near the middle of the dorsal side. The inner surface of both siphons are beautifully coloured in crimson, and without any minute spines. Many eudocarps are found on the inner surface of the mantle.

Branchial sac : Eight folds (VIII small) on the left side and seven on the right side. Longitudinal vessels arranged as follows : - -

left $\quad$ D. $2(22) 1(30) 2(29) 3(28) 3(29) 4(23) 2(21) 2$ (11) $3 \mathrm{~V}$.

right D. 2 (23) 1 (31) 2 (31) 3 (30) 3 (27) 3 (22) 3 (15) $3 \mathrm{~V}$.

Transverse vessels are arranged in the central part of the branchial sac in the scheme : - - large-small-medium-small-large -... Stigmata elongate, about 8 in a mesh. Parastigmatic vessels culways present. Tentacles 16, excluding small ones; branches in 2 orders. Dorsal tubercle rosette in form.

Alimentory system : Oesophagus very long, liver composed of the anterior half with longitudinal plications and the posterior half provided with many small Iobules. Anal margin plain.

Gonad : Gonals occur only on the left side, and are composd of nine long tubular organs placed parallel in the intestinal loop.

Remarks : Cynthia pachyderma OKa found at Misaki resembles closely the 
present new species in the external appearance of the animal, but it is provided with 9 folds on each side of the branchial sas, and with gonads on both sides of the body.
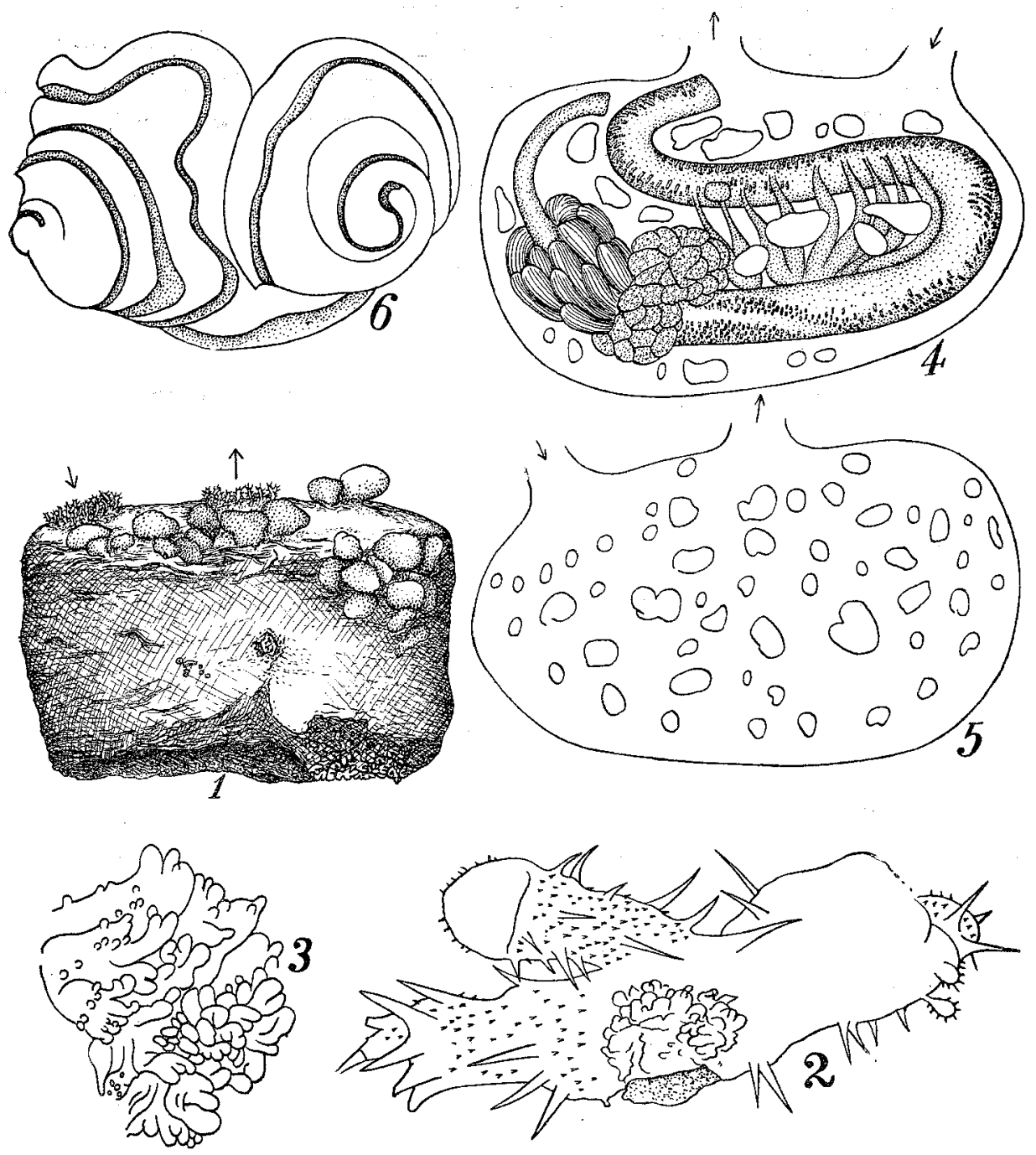

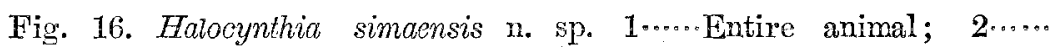
Spiny protuberance around the aperture, $\times 50 ; 3 \cdots \cdots$ Attachment processes; $4 \cdots .$. Left half, from inside; $5 \cdots .$. . Right half, from inside; $6 \cdots . .$. Dorsal tubercle, $\times 50$. 


\section{Explanation of Plate VIII}

Fig. 1. Pseudodistoma antinboja n.sp., entire colony.

Fig. 2. Symplegma reptans (OKA) a colony from Seto.

Fig. 3. Pyura michaelseni (OKA) entire animal.

Fig. 4. Pyura michaelseni (ОKA) var., depressa n. var. entire animal.

Fig. 5. Herdmania momus (SAvigny), large specimen (30 mm long).

Fig. 6. Herdmania momus (SAVIGNY), small specimen (10mm long). 
Publ. Seto Mar. Biol. Lab., I, 2 (1949)
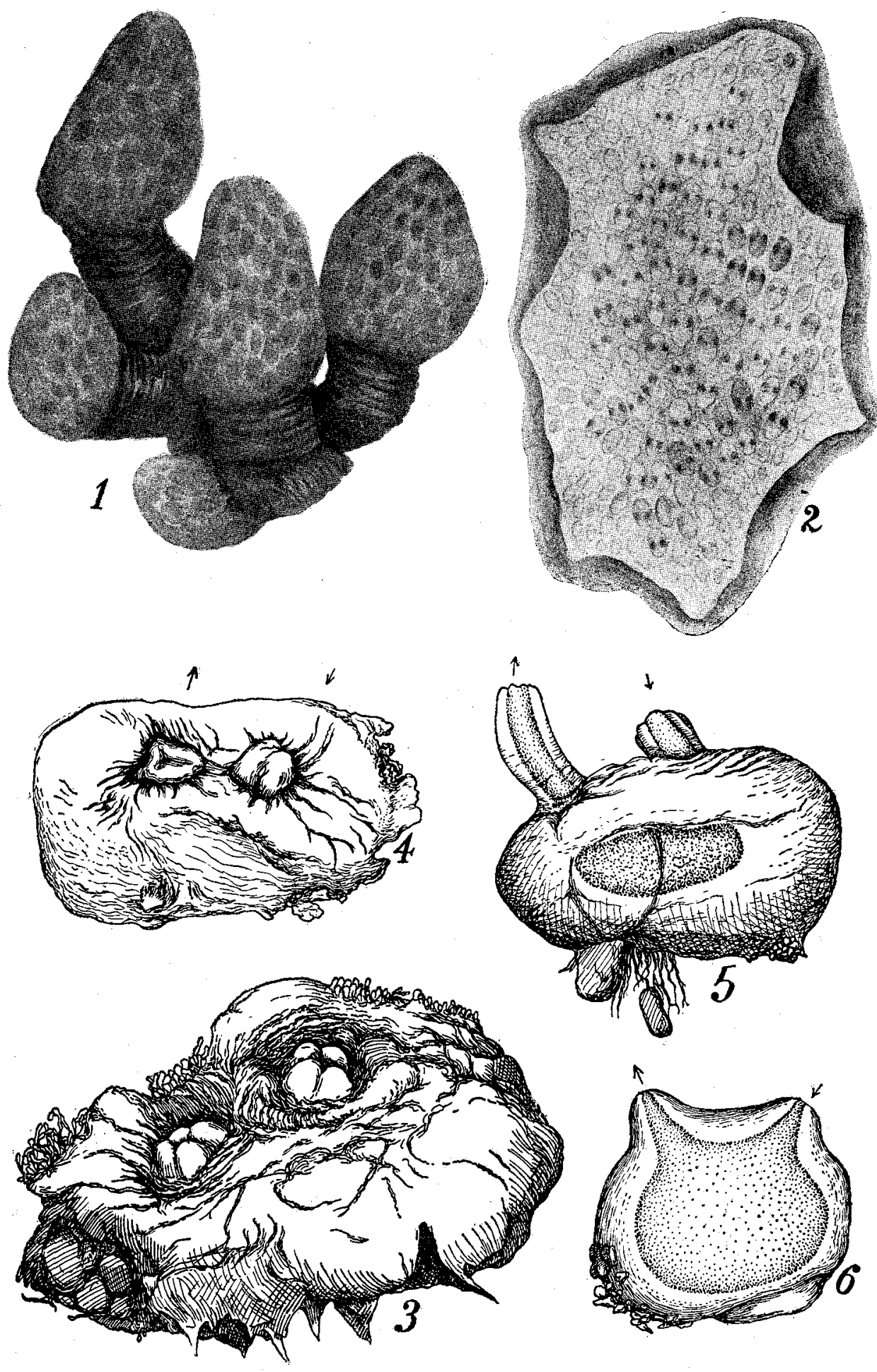